This analysis shows that the abnormal haemoglobin is not Haemoglobin Norfolk, which is $\alpha 57$ Gly $\rightarrow$ Asp and would give a similar fingerprint, though with another new peptide in addition to the one near $\alpha$ and $\beta$ TpVII (Baglioni, 1962), and where in contrast to the peptide found here the abnormal peptide would contain only one glycine residue. The analysis does, however, suggest that the abnormal peptide is derived from $\alpha \mathrm{TpVII}$. This is consistent with the fingerprint, which does not show any peptide to be absent ; since $\alpha$ and $\beta$ TpVII lie in the same position on fingerprints the absence of $\alpha \mathrm{TpVII}$ would not be visible. In normal haemoglobin $\alpha$ TpVII consists of $\alpha 57-60$ Gly-His-Gly-Lys. The C-terminal $\alpha 60$ lysyl is followed by another lysine residue in position 61 .

In order to determine the abnormal amino-acid, the new peptide was sequenced by the Edman-Dansyl technique (Gray, 1967). This showed that in the first and third residues of the peptide were both glycine and the fourth was aspartic acid (or, because of the electrophoretic mobility of the peptide, asparagine). The second residue was not detected, and can be assumed to be histidine, which does not dansylate easily. This sequence is consistent with the mutation $\alpha 60$ Lysine $\rightarrow$ Asparagine. The abnormal peptide seen on the fingerprints would be $\alpha 57-61$.

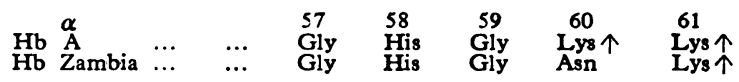

The arrows indicate points of cleavage on tryptic digestion.

This new Haemoglobin Zambia ( $\alpha 60$ Lysine $\rightarrow$ Asparagine) may well become an important genetic marker in parts of Central Africa.

\section{REPERENCES}

Baglioni, C. (1962). Fournal of Biological Chemistry, 237, 69 Gray, W. R. (1967). Methods in Enzymology, 11, 469. Sick, K., et al. (1967). Biochemica et Biophysica Acta, 140, 231.

\title{
Remission Induction with Cytosine Arabinoside and L-Asparaginase in Acute Lymphoblastic Leukaemia
}

\author{
T. J. MCELWAIN,* M.B., M.R.C.P. ; R. M. HARDISTY, † M.D., M.R.C.P., F.R.C.PATH.
}

\begin{abstract}
Summary: Nine patients with acute lymphoblastic leukaemia in relapse were treated with a course of cytosine arabinoside followed immediately by a course of L-asparaginase. Eight patients achieved complete remission of their disease. This combination of drugs is sufficiently effective to suggest that further trial is needed. It is possible that the combination has a synergistic effect.
\end{abstract}

\section{Introduction}

L-Asparaginase is now established as an effective agent for induction of remission in acute lymphoblastic leukaemia. Of 67 patients treated with L-asparaginase at the Memorial Hospital, New York, $63 \%$ achieved complete remission. Several different treatment regimens were used, with doses of 10, 200, 1,000 , and 5,000 i.u. $/ \mathrm{kg}$./day for 28 days. There was no significant difference between remission rates for dosages between 200 and 5,000 i.u./kg./day, but unmaintained remissions were longer in patients who had received 1,000 and 5,000 i.u./kg./day than in those who were given the lower dosages (F. L. Horsfall, personal communication, 1969). Tallal and Oettgen (1968) also reported remissions in six out of eight children with acute lymphoblastic leukaemia, who received $\mathrm{L}$-asparaginase in doses of 10 to $200 \mathrm{i}$.u. $/ \mathrm{kg}$. intravenously daily, given over three to six weeks.

Experience with the use of cytosine arabinoside (Ara-C) in acute lymphoblastic leukaemia suggests that a remission rate of $20-30 \%$ is to be expected (Ellison et al., 1968 ; Howard et al., 1968). On the basis of experience with other drug comblnations in acute lymphoblastic leukaemia it might be hoped that higher remission rates could be obtained with a combination of Ara-C and L-asparaginase. This is similar to the experience of Burchenal (1969) in mice with leukaemia EARAD F $_{1}$; he

* Leukaemia Research Fellow.

I Professor of Haematology. Street, London W.C.1. found that remission rates were higher with Ara-C and L-asparaginase together than when either drug was used alone.

We have treated a small series of patients with a course of Ara-C followed immediately by a course of $\mathrm{L}$-asparaginase, and though the number of patients is too small to draw any definite conclusions, preliminary results suggests that this is a highly effective combination for remission induction.

\section{Patients and Methods}

Nine patients aged 2 to 11 years with acute lymphoblastic leukaemia were treated. All had previously received other antileukaemic drugs and were in a second or subsequent relapse except Case 1, who had relapsed for the first time (see Table I). At the time of relapse seven patients had between 12.5 and $94.5 \%$ of leukaemic cells in the bone marrow; of the other two, whose marrow was not examined at this stage, one had 60,000 and the other 13,000 leukaemic cells/cu. mm of peripheral blood.

Treatment was started with Ara-C $3 \mathrm{mg} . / \mathrm{kg}$. intravenously daily. The course ranged from 5 to 14 injections given over 5 to 24 days. Bone marrow was examined at the end of the course of Ara-C, and treatment with $\mathrm{L}$-asparaginase 1,000 i.u./ $\mathrm{kg}$. intravenously daily was then started. In none of the patients did the bone marrow show less than $10 \%$ leukaemic cells at the end of the course of Ara-C.

Two types of L-asparaginase were used: Escherichia coli material supplied by Farbenfabriken Bayer A.G. (Cases 1 to 7 ) and Erwinia carotovorum material from the Microbiological Research Establishment, Porton Down, Salisbury (Cases 8 and 9). L-Asparaginase was given for 9 to 28 days, treatment being continued until there was a sustained rise in the patients' neutrophil and platelet counts. The bone marrow was then re-examined and if it showed remission L-asparaginase was discontinued. Full supportive therapy with packed red cells, platelet-rich plasma, and antibiotics was given whenever indicated during the course of treatment with Ara-C and L-asparaginase. 
In six patients the in-vitro test for sensitivity of leukaemic cells to L-asparaginase was attempted, bone marrow obtained immediately before the start of treatment with L-asparaginase being used. In three the test was technically unsatisfactory owing to bone-marrow hypocellularity, and in the others the test predicted the result of treatment correctly in two (Cases 7 and 9) and incorrectly in one (Case 2), who obtained a remission, though the test suggested that the leukaemic cells were insensitive to $\mathrm{L}$-asparaginase.

\section{Results -}

Eight of the nine patients achieved complete remission (Table I). The patients fall into three groups: six (Cases 1-6) in whom the proportion of leucaemic cells in the bone marrow was reduced by Ara-C, but in whom complete remission did not occur while the patient was receiving this drug, but did occur after treatment with L-asparaginase; two (Cases 7 and 8 ) in whom the leukaemic-cell count in the bone marrow rose during treatment with Ara-C, but in whom remission occurred after receiving L-asparaginase; and one (Case 9) in whom the circulating leukaemic cells increased progressively during both Ara-C and L-asparaginase treatment and who failed to achieve remission (Table II).

\begin{tabular}{|c|c|c|c|c|c|c|c|}
\hline \multicolumn{6}{|c|}{ TABLE I.-Treatment $S$} & \multicolumn{2}{|l|}{ Summary } \\
\hline $\begin{array}{l}\text { Case } \\
\text { No. }\end{array}$ & Age & Sex & $\begin{array}{c}\text { No. of } \\
\text { Relapse }\end{array}$ & $\begin{array}{c}\text { Time } \\
\text { since } \\
\text { Diagnosis } \\
\text { (Weeks) }\end{array}$ & $\begin{array}{c}\text { Ara-C } \\
3 \text { mg./kg. } \\
\text { i.v. Daily. } \\
\text { No. of } \\
\text { Days' } \\
\text { Treatment }\end{array}$ & $\begin{array}{c}\text { L-Aspara- } \\
\text { ginase } \\
\text { 1,000 i.u. } / \mathrm{kg} . \\
\text { Daily; } \\
\text { Days; } \\
\text { Treatment }\end{array}$ & Result \\
\hline $\begin{array}{l}1 \\
2 \\
3 \\
4 \\
5 \\
6 \\
7 \\
8 \\
9\end{array}$ & $\begin{array}{r}2 \\
5 \\
11 \\
5 \\
6 \\
6 \\
5 \\
5 \\
6\end{array}$ & \begin{tabular}{|c|}
$\mathbf{F}$ \\
$\mathbf{M}$ \\
$\mathbf{M}$ \\
$\mathbf{M}$ \\
$\mathbf{M}$ \\
$\mathbf{F}$ \\
$\mathbf{F}$ \\
$\mathbf{F}$
\end{tabular} & $\begin{array}{l}1 \\
3 \\
2 \\
4 \\
3 \\
3 \\
\mathbf{4} \\
\mathbf{4} \\
\mathbf{3}\end{array}$ & $\begin{array}{r}17 \\
71 \\
78 \\
100 \\
101 \\
119 \\
98 \\
50 \\
73\end{array}$ & $\begin{array}{r}10 \\
14 \\
7 \\
8 \\
10 \\
10 \\
9 \\
13 \\
5\end{array}$ & $\begin{array}{l}21 \\
14 \\
21 \\
21 \\
28 \\
18 \\
21 \\
14 \\
9\end{array}$ & $\begin{array}{l}\text { Remission } \\
\text { Remission } \\
\text { Remission } \\
\text { Remission } \\
\text { Remission } \\
\text { Remission } \\
\text { Remission } \\
\text { Remission } \\
\text { Failed. Blast } \\
\text { count continued } \\
\text { to rise on Ara-C } \\
\text { and asparaginase }\end{array}$ \\
\hline
\end{tabular}

Neutropenia and thrombocytopenia were constant findings during Ara-C administration. In some cases the platelet count fell to below $10,000 / \mathrm{cu}$. $\mathrm{mm}$. and the neutrophil count to below $100 / \mathrm{cu}$. mm., as, for example, in Case 1 (see Chart). During treatment with L-asparaginase, however, the neutrophil and platelet counts rose. Furthermore, there was always hypoplasia of the normal bone-marrow elements after Ara-C administration, irrespective of whether the percentage of leukaemic cells had risen or fallen. Neutropenia and severe marrow hypoplasia were the factors which made us decide to stop Ara-C therapy in those patients in whom there had been reduction in the bone-marrow leukaemic cells while the drug was being given.

The remissions obtained were maintained in a variety of ways, so that the patients are not comparable in respect of duration of remissions. The choice of maintenance agent was determined by the previous history. Four of the eight patients had previously relapsed on mercaptopurine, methotrexate, and cyclophosphamide, so these drugs could not be used; three of these patients received non-specific immunotherapy with pertussis antigen $0.5 \mathrm{ml}$. subcutaneously weekly, and one received L-asparaginase 1,000 i.u. intravenously twice weekly. Three patients had not previously received cyclophosphamide

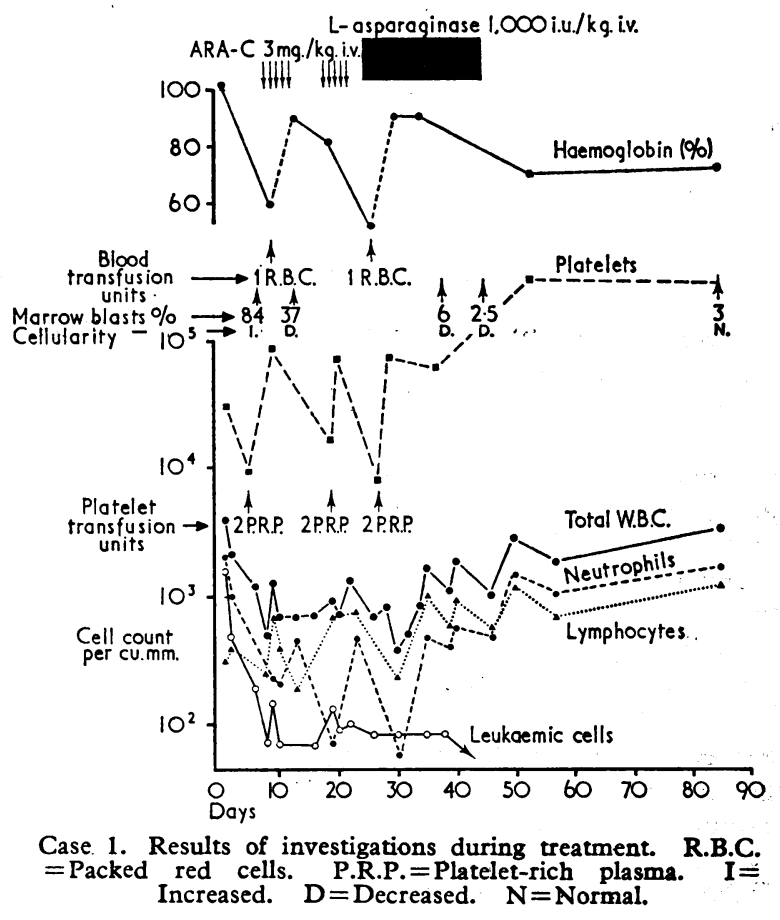

and were maintained on this drug with $3 \mathrm{mg} . / \mathrm{kg}$. by mouth daily, and the eighth patient was maintained on mercaptopurine $2.5 \mathrm{mg} . / \mathrm{kg}$. by mouth daily. The length of remissions ranged from 6 to 21 weeks and all of the eight patients have now relapsed. Case 9, in-whom remission did not occur, died two weeks after L-asparaginase was stopped, following an unsuccessful attempt to induce remission with daunorubicin.

\section{Discussion}

The results obtained in this small series are most encouraging, since not only did all but one of the patients obtain a complete remission, but most of these remissions occurred at a period when the disease was at an advanced stage, having become refractory to most other forms of treatment. Furthermore, induction was smooth and mainly without complication, though it should be emphasized that facilities for platelet transfusion must be available for the treatment of the thrombocytopenia that almost invariably develops with Ara-C therapy. Some of the remissions were disappointingly short, but this may be attributable to lack of adequate maintenance agents at this late stage of the disease.

An important question which is left unanswered is whether previous treatment with Ara-C enhances the action of

TABLE II.-Bone Marrow Findings

\begin{tabular}{|c|c|c|c|c|c|c|c|c|}
\hline \multirow{2}{*}{ Case No. } & \multicolumn{2}{|c|}{ Before Ara-C } & \multicolumn{2}{|c|}{ After Ara-C } & \multicolumn{2}{|c|}{ After L-Asparaginase } & \multicolumn{2}{|c|}{ Subsequent } \\
\hline & Cellularity & Blasts (\%) & Cellularity & Blasts (\%) & Cellularity & Blasts (\%) & Cellularity & Blasts (\%) \\
\hline $\begin{array}{l}1 \\
3 \\
3\end{array}$ & $\begin{array}{c}\text { Increased } \\
\text { Normal } \\
\text { Leukaemic cells } \\
\text { blood }\end{array}$ & $\begin{array}{c}84 \\
84 \\
13,000 / \text { cu.mm. in }\end{array}$ & $\begin{array}{l}\text { Decreased } \\
\text { Decreased } \\
\text { Decreased }\end{array}$ & $\begin{array}{l}37 \\
68 \cdot 5 \\
30\end{array}$ & $\begin{array}{l}\text { Decreased } \\
\text { Decreased } \\
\text { Normal }\end{array}$ & $\begin{array}{l}2.5 \\
0.5 \\
0.5\end{array}$ & $\begin{array}{l}\text { Normal } \\
\text { Normal }\end{array}$ & $\begin{array}{l}3 \cdot 5(6)^{*} \\
4.5(5)\end{array}$ \\
\hline $\begin{array}{l}4 \\
5 \\
6\end{array}$ & $\begin{array}{l}\text { Increased } \\
\text { Increased } \\
\text { Normal }\end{array}$ & $\begin{array}{l}47 \\
94 \cdot 5 \\
50\end{array}$ & $\begin{array}{l}\text { Decreased } \\
\text { Decreased } \\
\text { Decreased }\end{array}$ & $\begin{array}{l}11 \\
20.5 \\
19\end{array}$ & $\begin{array}{l}\text { Decreased } \\
\text { Normal } \\
\text { Decreased }\end{array}$ & $\begin{array}{l}6 \\
0.3 \\
0.5\end{array}$ & Increased & 2 (9) \\
\hline $\begin{array}{l}7 \\
8\end{array}$ & $\begin{array}{l}\text { Increased } \\
\text { Normal }\end{array}$ & $\begin{array}{l}12.5 \\
20 \cdot 5\end{array}$ & $\begin{array}{l}\text { Increased } \\
\text { Increased }\end{array}$ & $\begin{array}{l}99 \\
86.5\end{array}$ & $\begin{array}{l}\text { Normal } \\
\text { Decreased }\end{array}$ & 2 & Normal & $1.5(2)$ \\
\hline 9 & $\begin{array}{c}\text { Leukaemic cells } \\
\text { blood }\end{array}$ & $60,000 /$ cu.mm. in & Increased & 79 & $\begin{array}{l}\text { Leukaemic cell } \\
\text { on treatment }\end{array}$ & in blood rose & & \\
\hline
\end{tabular}


L-asparaginase or whether their effects are quite independent. For example, it might be argued that those patients in whom the number of leukaemic cells in the bone marrow fell on treatment with Ara-C would have achieved remission with this drug alone had further doses been given. It was felt that to continue giving Ara-C to patients who were already grossly neutropenic would have involved a considerable risk of infection, while to withhold all treatment was unnecessary and unjustifiable when L-asparaginase was available. Indeed, our results illustrate that a major advantage of $\mathrm{L}$-asparaginase over other antileukaemic drugs is that it may be used to treat patients In whom the bone marrow is severely hypoplastic without producing further marrow depression. They confirm the findings of other workers who have found that L-asparaginase is nontoxic to normal bone-marrow elements.

At a purely speculative level it may be suggested that the bone-marrow hypoplasia produced by Ara-C serves to enhance the effectiveness of L-asparaginase, since the removal of normal cells from the bone marrow depletes a source of the extrinsic L-asparagine which the leukaemic cells require. Since L-asparaginase is unable to penetrate cell membranes or enter the extracellular fluid it can only hydrolyse circulating L-asparagine, leaving the leukaemic cells with a second source of the amino-acid - that obtained by diffusion from those normal cells with which they are in direct contact in the bone marrow. Thus if the number of normal cells is reduced, further "starvation" of the leukaemic cells may result.

Another way in which Ara-C might increase the sensitivity of the leukaemic cells to the action of $\mathrm{L}$-asparaginase is by synchronization of the mitotic cycle following inhibition of reproduction. This is known to occur with HeLa cells (Kim and Eidinoff, 1965), and a similar effect has been observed with leukaemic cells (Lampkin et al., 1969), so it may be that synchrony permits greater cell kill by another antitumour agent to which the dividing cells are sensitive.
These preliminary results are encouraging enough to suggest the need for a controlled trial of such treatment, and this is now being undertaken. It would seem appropriate also to compare the effect of giving both drugs together, with their sequential use. If both these types of treatment were found to give equally satisfactory results, there would be a theoretical advantage in using the two drugs sequentially rather than together, since patients achieving remission on Ara-C alone would then be able to receive L-asparaginase for the first time in a subsequent relapse, either alone or after further Ara-C. This is illustrated by Case 4 , who had received a course of Ara- $\mathrm{C}$ in a previous relapse and who had achieved complete remission on that occasion.

We should like to thank the physicians of the Hospital for Sick Children who have allowed us to study patients under their care and to participate in their management. We are grateful to Dr. H. B. Allen, of F.B.A. Pharmaceuticals Ltd, and Dr. C. E. Gordon Smith, the Microbiological Research Establishment, Porton Down, Salisbury, for supplies of $\mathrm{L}$-asparaginase, and to Dr. W. P. Goodyear, of Upjohn Ltd., for cytosine arabinoside (cytarabine). The in-vitro asparaginase sensitivity tests were kindly carried out by Dr. D. Crowther and Mr. R. L. Sewell at the Chester Beatty Research Institute, Sutton. This work was supported by a grant from the Leukaemia Research Fund.

\section{REFERENCES}

Burchenal, J. H. (1969). Cancer Research. In press.

Ellison, R. R., et al. (1968). Blood, 32, 507.

Howard, J. P., Albo, V., and Newton, W. A., jun. (1968). Cancer, 21, 341 .

Kim, J. H., and Eidinoff, M. L. (1965). Cancer Research, 25, 698.

Lampkin, B. C., Nagao, T., and Mauer, A. M. (1969). Journal of Clinical Investigation, 48; 1124.

Tallal, L., and Oettgen, H. (1968). Proceedings of the American Association for Cancer Research, 9, 70.

\section{Preliminary Communications}

\section{Proteins and Insulin Release : A Dual Role of Amino-acids and Intestinal Hormones}

British Medical fournal, 1969, 4, 598-600

$S^{\mathrm{un}}$ mmary : In two subjects concurrent infusion of amino-acids and the hormones secretin and pancreozymin provoked much higher plasma insulin levels than did administration of amino-acids or hormones levels than did administration of amidually. It is suggested that this may be a physiological phenomenon, augmenting the release of insulin from the pancreas after a meal containing protein.

\section{INTRODUCTION}

The first, indirect, evidence that amino-acids might stimulate insulin release was provided by Mellinkoff et al. (1955). Subsequently, several authors have shown that, in man, amino-acids, whether given orally or intravenously, or protein meals increase the level of circulating plasma insulin (Berger and Vongaraya, i966; Floyd et al., 1966 ; Rabinowitz et al., 1966). There is considerable variation in the insulin response to individual amino-acids, arginine generally being the most potent stimulant. Certain amino-acids also stimulate insulin release in vitro (Malaisse and Malaisse-Lagae, 1969 ; Turner, 1969), so that one possible explanation of the insulinotropic action of protein foods is through direct pancreatic stimulation by the aminoacids resulting from digestion. Alternatively, the hormones secretin and pancreozymin, both secreted in response to protein foods and both known to stimulate insulin release, may be responsible, either alone or by interaction with amino-acids, for the insulinotropic effect. The latter possibility is the subject of the present investigation.

\section{MATERIAL AND METHODS}

Two volunteer subjects were investigated on several occasions after an overnight fast. While lying at rest constant infusions of (1) physiological saline, (2) amino-acids, (3) pancreozymin, (4) secretin, or (5) combinations of $1-4$ were made into a vein of one arm; blood samples were collected from an indwelling venous catheter in the other.

Amino-acids were administered as a casein hydrolysate (Aminosol 10\%), kindly provided by Dr. P. C. Allen, of Messrs. Paines and Byrne Ltd. Purified preparations of pancreozymin 